\title{
"Those are Your Words, Not Mine!" Defence Strategies for Denying Speaker Commitment
}

\author{
Ronny Boogaart ${ }^{1} \cdot$ Henrike Jansen ${ }^{2} \cdot$ Maarten van Leeuwen $^{3}$ (D)
}

Published online: 23 May 2020

(c) The Author(s) 2020

\begin{abstract}
In response to an accusation of having said something inappropriate, the accused may exploit the difference between the explicit contents of their utterance and its implicatures. Widely discussed in the pragmatics literature are those cases in which arguers accept accountability only for the explicit contents of what they said while denying commitment to the (alleged) implicature ("Those are your words, not mine!"). In this paper, we sketch a fuller picture of commitment denial. We do so, first, by including in our discussion not just denial of implicatures, but also the mirror strategy of denying commitment to literal meaning (e.g. "I was being ironic!") and, second, by classifying strategies for commitment denial in terms of classical rhetorical status theory (distinguishing between denial, redefinition, an appeal to 'external circumstances' or to a 'wrong judge'). In addition to providing a systematic categorization of our data, this approach offers some clues to determine when such a defence strategy is a reasonable one and when it is not.
\end{abstract}

Keywords Speaker commitment · Denying accountability · Defence strategies · Status theory $\cdot$ Implicature $\cdot$ Semantics-pragmatics interface $\cdot$ Plausible deniability

Ronny Boogaart

r.j.u.boogaart@hum.leidenuniv.nl

Henrike Jansen

h.jansen@hum.leidenuniv.nl

Maarten van Leeuwen

m.van.leeuwen@hum.leidenuniv.nl

1 Leiden University Centre for Linguistics (LUCL), P.N. van Ecykhof 1/room 205C, P.O.

Box 9515, 2300 RA Leiden, The Netherlands

2 Leiden University Centre for Linguistics (LUCL), P.N. van Ecykhof 1/room 204A, P.O. Box 9515, 2300 RA Leiden, The Netherlands

3 Leiden University Centre for Linguistics (LUCL), P.N. van Ecykhof 1/room 106A, P.O. Box 9515, 2300 RA Leiden, The Netherlands 


\section{Introduction}

In February 2017, James Comey, FBI Director at the time, was asked by president Trump to end the investigation into former National Security Advisor Michael Flynn and his contacts with the Russian ambassador. ${ }^{1}$ This at least is what Comey testified to the Senate Intelligence Committee. Since such a request would constitute obstruction of justice, it was hotly debated whether or not Trump actually made this request to Comey when he allegedly uttered the words in (1).

(1) I hope you can see your way to letting this go, to letting Flynn go. He is a good guy. I hope you can let this go.

While Trump himself denied having uttered these words altogether, his fellow Republicans took another defence line by pointing out that (1) is an expression of a personal feeling rather than a directive. One of Trump's sons added that whenever his father ordered something, it was always clear that his words were meant as an order and this was not the case here (Capone and Bucca 2018). Literally speaking, in (1), Trump indeed expresses his hope that Comey will "let this go", but Comey understood these words to mean that he should do so. In terms of Grice's framework (1975), the latter would be considered a conversational implicature of (1).

The above case illustrates how one can exploit the difference between the literal content of an utterance and its implicatures. The Republican defence accepts responsibility only for the explicit content of the utterance and denies commitment to a possible implicature. This response is an instantiation of step 3 in Fig. 1 below, where step 1 represents the original utterance itself, and step 2 the accusation resulting from an assessment of the supposed implicature as unacceptable for whatever reason (juridically, morally etc.).

Was it reasonable for the Republicans to deny Trump's commitment to the directive interpretation of (1)? This question relates to an important issue of debate in present day pragmatics, dealing with the extent to which speakers are committed to implicatures of what they literally say. This is manifest, most notably, in recent discussions about the question whether untruthful implicatures constitute lying (Meibauer 2014) ${ }^{2}$ or are "merely" misleading (Oswald 2010; Saul 2012; Dynel 2018; Weissman and Terkourafi 2018). Outside the debate about lying, there is a strand of research proposing that commitment is a graded notion and that different kinds of implicit content carry different degrees of commitment on the part of the speaker (Morency et al. 2008; de Saussure and Oswald 2009; Moeschler 2013; Mazzarella et al. 2018). As these studies make clear, however, the assessment of commitment is complicated by the fact that "the speaker's actual mental states regarding the utterance (...) cannot be accessed directly" (Morency et al., ibidem, p. 202). There

\footnotetext{
1 We thank the anonymous reviewers and Steve Oswald for their useful comments on an earlier version of this paper. All remaining mistakes are of course our own.

2 "I assume that the speaker is committed to the truth of a conversational implicature in the same way as they are committed to the truth of an assertion" (Meibauer 2014, p. 108).
} 


\begin{tabular}{|l|l|}
\hline & Denying implicature \\
\hline Step 1 & Speaker says $\mathrm{p}$ and may implicate $\mathrm{q}$ \\
Step 2 & Hearer holds speaker accountable for $\mathrm{q}$ \\
Step 3 & Speaker denies commitment to q \\
\hline
\end{tabular}

Fig. 1 Denying commitment to an implicature

is, for instance, no way of knowing for sure if Trump intended his utterance in (1) to be interpreted as a directive speech act. In this paper we therefore try to contribute to the study of commitment by focusing on another aspect of this phenomenon. Current approaches, mostly relying on standard or fictional examples, are basically concerned with the first two steps in the scenario of Fig. 1, i.e. with the speaker's own commitment (step 1) and the way the utterance is interpreted by the hearer on the basis of pragmatic reasoning (step 2). In our view, the study of speaker commitment may benefit from looking at the third step in this figure, by investigating the ways in which speakers, in reality, defend themselves against an interpretation of their words that they do not accept. ${ }^{3}$

Moreover, our study of commitment includes the mirror scenario of denying commitment to literal meaning. In this scenario, arguers deny that they are committed to what they literally said and accept responsibility only for the implicature. This type of defence was, for instance, used by the CEO of the political consultancy firm Cambridge Analytica, saying that his remarks, to an undercover reporter, about unethical methods for discrediting political opponents, had been spoken "with a certain amount of hyperbole" (BBC Newsnight, March 20 2018) (Branum 2018). ${ }^{4}$ Whereas in the Trump case in (1), an implicature is being denied, in this case the speaker does not accept responsibility for the literal content of what was said.

In sum, the goal of our paper is to investigate how speakers manage commitment to their utterances, by studying step 3 in the two scenarios depicted in Fig. 2:

\footnotetext{
${ }^{3}$ Galasinski (2002), when looking at evasion, does something similar by looking at the reactions to potentially deceptive statements for deciding whether a given utterance is probably deceptive. Jackson, Jacobs and Zang (to appear) study examples similar to ours in order to show that standpoints 'get constructed through interaction as participants discover what they themselves are prepared to assert'.

${ }^{4}$ https://www.vice.com/en_us/article/7xdpae/cambridge-analytica-data-uk-government. See Snoeck Henkemans (2017) and Boogaart (2020) on the use of hyperbole as a strategic manoeuvre in argumentation.
} 


\begin{tabular}{|l|l|l|}
\hline & Scenario 1: Denying literal meaning & Scenario 2: Denying implicature \\
\hline Step 1 & Speaker says $\mathrm{p}$ and may implicate $\mathrm{q}$ & Speaker says $\mathrm{p}$ and may implicate $\mathrm{q}$ \\
Step 2 & Hearer holds speaker accountable for $\mathrm{p}$ & Hearer holds speaker accountable for $\mathrm{q}$ \\
Step 3 & Speaker denies commitment to $\mathrm{p}$ & Speaker denies commitment to $\mathrm{q}$ \\
\hline
\end{tabular}

Fig. 2 Two kinds of commitment denial exploiting the explicit/implicit distinction

We do so by looking at the reasons speakers give to support their denials of commitment to something they (allegedly) said or implicated. We claim that the plausibility of the reasons used to back up denials of commitment provides us with clues for the assessment of commitment. To be more precise: degree of speaker commitment may be related to the question of how plausible we judge the reasons given to deny commitment to the literal contents of an utterance or to its implicatures. ${ }^{5}$

We will start, in Sect. 2, with outlining some relevant pragmatic background: first by comparing our notion of deniability to the Gricean notion of "cancellability" and then by discussing the explicit/implicit distinction in light of the Gricean typology of implicatures. In Sect. 3 we will discuss some case studies of the two scenarios, illustrating different defence strategies that arguers make use of when denying commitment. In Sect. 4 we will classify the strategies identified in Sect. 3 in terms of classical-rhetorical status theory, and reflect on how this classification provides clues for the assessment of speaker commitment.

\section{Denying Commitment}

\subsection{Denial versus Cancellation}

In both scenarios we are investigating in this paper, as summarized in Fig. 2, the speaker is denying commitment, either to a possible implicature of his utterance or to the literal contents of the utterance itself. This phenomenon, i.e. denial of commitment, shows some overlap with Grice's (1975) notion of cancellability, which is much more widely discussed in the pragmatics literature. However, the two should not be confused.

Grice (1975) introduced cancellability as a means to distinguish between explicit content, or "what is said", and conversational implicatures; according to Birner (2013, p. 69), cancellability "is perhaps the most commonly used test for conversational implicatures". In his original paper, Grice (1975, p. 39) specifies two ways in which a conversational implicature can be canceled:

\footnotetext{
5 Whenever step 3 constitutes a reasonable defence, the hearer in step 2 may have committed a straw man fallacy. The latter, however, is not the focus of this paper.
} 
It may be explicitly canceled, by the addition of a clause that states or implies that the speaker has opted out, or it may be contextually canceled, if the form of the utterance that usually carries it is used in a context that makes it clear that the speaker is opting out.

The utterance in (2), for instance, usually carries the implicature that the speaker does not have more than two sons:

(2) I have two sons.

In (3) and (4) illustrations are given of the two ways in which the implicature that the speaker has only two sons can be cancelled:

(3) I have two sons. In fact, I have three sons and a daughter.

(4) A: We are looking for a father and two sons for our advertising campaign.

Do you happen to have two sons?

B: Yes, I have two sons.

Whereas in (3) the speaker explicitly cancels the implicature, in (4) the context makes clear that the implicature is not necessarily true since in the context of A's question other sons or daughters are irrelevant. On the basis of (3) and (4) we may thus conclude that in (2) the information that the speaker does not have more than two sons is an implicature rather than part of what is said.

The fact that the implicature of (2) is cancellable does, however, not mean that the speaker can deny the implicature just like that at a later stage. ${ }^{6}$ Suppose your new colleague at work tells you she has two sons [as in (2)] and much later you find out that she has three sons and one daughter. When you accuse her of lying and she defends herself by saying (5), this is not Gricean-type cancellation but an instance of what we consider denial of commitment. ${ }^{7}$

(5) I only said I have two sons, I never meant to say that I do not have more than two sons and no daughters.

Just like the Republican defence of Trump's words in (1), your colleague's answer in (5) constitutes the denial of an implicature, but perhaps even more than in (1) it is clear that (5) is not a reasonable denial. Even though the speaker's denial of the default reading ("not more than two") may be logically consistent with her original utterance, that is not sufficient for making the denial a reasonable one from a pragmatic point of view (cf. de Saussure and Oswald 2009; Morency et al. 2008;

\footnotetext{
${ }^{6}$ In the words of Mazzarella et al. (2018, p. 16), "a content is deniable if the speaker can deny (when openly challenged) to have had the intention to communicate it in the first place".

7 Immediate and explicit cancellation may of course be regarded as one of the ways to deny commitment, but we are proposing a terminological distinction between Gricean type cancellation and the phenomenon we are investigating in this paper. Our point is that cancellability in a Gricean sense does not equal deniability at a later stage.
} 
Moeschler 2013; Mazzarella et al. 2018). In fact, in the empirical research of lies reported on by Weissman and Terkourafi (2018), such a case involving the denial of an implicature associated with the use of a cardinal number, got a mean rating of 6.5 on a scale ranging from 1 ("definitely not a lie") to 7 ("definitely a lie"). In this respect, the use of cardinal numbers may constitute a rather special case (Horn 2009), but it suffices as a clear illustration of how Gricean cancellability works and how it is different from deniability.

Thus, if a speaker denies commitment to an implicature at a later stage, in response to an accusation, then this is quite different from cancellation in a Gricean sense, as in (3), that is overt and immediate and "volunteered" by the speaker himself. ${ }^{8}$ In the case of explicit cancellation, holding the speaker accountable for the implicature does, of course, not make sense and is unreasonable itself. The same is true in principle if the implicature is cancelled by context, as in (4), but in such cases there may be disagreement about how suggestive the context is of a specific interpretation, as in the Trump case in (1) and in fact many of the cases to be discussed in Sect. 3.

\subsection{Types of Implicature and Degrees of Commitment}

Our representation of the two scenarios in Fig. 2 may suggest that there is a sharp boundary between literal and implicated meaning. However, this distinction is, of course, not so clear-cut and has occupied pragmaticians for a very long time. Below we will show that variation in degrees of commitment is not entirely a matter of "what is said" versus implicatures in a Gricean sense. More specifically, Grice's conventional implicatures and generalized conversational implicatures pretty much behave like explicit content when it comes to deniability. ${ }^{9}$

\subsubsection{Conventional Implicature}

Grice used the term conventional implicature, as opposed to conversational implicature, for those elements of utterance interpretation that are clearly attached to a specific form but that do not, in his view, contribute to the truth-conditional content of the utterance. Since Grice restricted his notion of "what is said" to truth-conditional meaning, such aspects in his account need to be treated as implicatures. Grice's own example concerns the interpretation of therefore in He is an Englishman; he is, therefore, brave. On this example, Grice (1975, p. 44) explicitly comments that the speaker has "certainly committed" himself to the implicature that being English necessarily means being brave. In fact, as opposed to conversational implicatures, conventional implicatures cannot be cancelled and, in this respect, they behave like the explicit contents

\footnotetext{
8 Another aspect in which our notion of denial crucially differs from the Gricean notion of cancellation is that we assume that the speaker may also deny commitment to the literal contents of what they said (see case studies in Sect.3.1).

9 Relevance Theory treats these types of implicatures as part of coded meaning (conventional implicatures) or as explicatures (generalized conversational implicatures). Adopting this terminology, Morency et al. (2008) assume that explicatures carry the highest degree of commitment, on a par with coded meaning, whereas implicatures can be situated on a scale from high to low speaker commitment, depending on their degree of relevance in a particular context.
} 
of an utterance. This is also true for denial, as is illustrated in (6), where the Dutch comedian Richard Groenendijk is denying commitment to a conventional implicature.

(6) They did not have children, so they were happy

[audience laughs]

No, I did not mean that!

(Richard Groenendijk in his show Met de mantel der liefde, broadcast by RTL4 on January 4 2019)

In the first utterance, Groenendijk, by using so, communicates that having children typically makes people unhappy. This implicature is clearly what the audience picks up on when it starts laughing (representing step 2 in our scenario in Fig. 2) and it is what Groenendijk refers to with that in his second utterance (step 3). However, being a conventional implicature of the connector so, it cannot be denied as simply as that. If the speaker did not "mean that", then they should not have used the word so. In our approach, the speaker may deny commitment to conventional implicatures, but to do so they will need to use the strategies of scenario 1 (denying literal meaning) rather than scenario 2 (denying implicature). ${ }^{10}$

\subsubsection{Generalized Conversational Implicature}

Like a conventional implicature, a generalized conversational implicature (GCI) is triggered by specific linguistic elements in an utterance. ${ }^{11}$ This was illustrated by means of the utterance in (2), where two (sons) is, by default, interpreted as implicating not more than two (sons). The difference between GCI's on the one hand and conventional implicatures and explicit meaning on the other hand is that in the case of GCI's, speakers may try to get away with accepting commitment only for the explicit content of what they said, since in these cases there actually is such a layer of "literal" meaning to be distinguished from the implicature. In fact, this is what your colleague tried to do in (5). Also, the defence of the non-directive reading of Trump's words in (1) would be a case in point.

(1) I hope you can see your way to letting this go, to letting Flynn go. He is a good guy. I hope you can let this go.

By claiming that Trump was only expressing a personal feeling of hope, the Republican defence is neglecting the fact that explicitly stating the sincerity condition of a directive speech act is a conventionalized way to indirectly perform a directive speech

\footnotetext{
10 The same holds for logical entailment, which, according to Moeschler (2013), constitutes the strongest form of inference, with the highest degree of speaker commitment. Thus, when the question Does John drink slivovitz? is responded to by saying He does not drink any alcohol (Carston 2002, p. 139) the speaker commits herself to having said that John does not drink slivovitz. To deny this, she will have to take recourse to strategies from scenario 1, such as claiming the utterance to have been ironic.

11 The most elaborate study of GCI's to date is still Levinson (2000).
} 
act (Searle 1975, p. 65) and, certainly in situations in which the speaker has authority over the hearer, this reading of (1) may thus well be regarded as a GCI. ${ }^{12}$ However, since the literal reading of such utterances is still accessible, arguers may appeal to this layer of explicit meaning in defence of an accusation, which is exactly what some Republicans did. This is not unreasonable a priori since, after all, conventionalization is a matter of degree and it is difficult to determine at which point exactly such an implicature is, or has become, a "generalized" or even a "conventional" one.

\subsubsection{Particularized Conversational Implicature}

If an implicature is not by default attached to a specific linguistic form but entirely dependent on the context, we are dealing with a particularized conversational implicature. In such cases there is, so to speak, less linguistic evidence for the implicature in the utterance itself. This, however, does not mean that a particularized implicature is necessarily easier to deny than a conventional or a generalized one.

As an example, we may consider the interpretation of the noun phrase kwetsbare informatie ('delicate information') as it was used by MP Ard van der Steur in commenting on a draft letter of the then Minister of Safety and Justice to inform parliament about a financial deal with a drug criminal. In January 2017, use of these words constituted one of the reasons why van der Steur, who had by then become Minister of Safety and Justice himself, resigned following a debate in parliament about the drug deal. The information in the letter that van der Steur had characterized as kwetsbaar ('delicate') concerned the amount of money that was paid to the drug criminal in exchange for his testimony. This information never made it to the final version of the letter and parliament would remain ignorant about the number for years to come. When the draft letter, including the comments, finally surfaced, it was claimed that van der Steur, by pointing out that the information was delicate, not only asserted that this was the case but had actually suggested to remove it from the letter. This clearly counts as a particularized implicature since there is no context independent connection between information being delicate and information being removed from a letter. (In other contexts, it might be advised for delicate information to be shared.) In fact, van der Steur himself denied that this is what he had meant and defended himself by claiming that if this were his intention, then he "would have said so explicitly". The reasonableness of this defence is hard to assess: given that "remove" is at best a particularized implicature of the word delicate in specific contexts, van der Steur could deny that it was his intention to have the information removed from the letter, and we cannot exclude the possibility that he was being sincere about this. One should, however, also allow for the possibility that such an implicature could be a conventional way of speaking in specific activity types or within a certain community, in the sense that the intended readership of van der Steur's original comments, the department of Justice and specifically the then Minister Opstelten, could have understood that this was in fact an intended implicature.

\footnotetext{
12 This may be more evident in phrasings such as "I would like you to", but "I hope you'll do it" is explicitly mentioned by Searle in his list of "sentences that could quite standardly be used to make indirect requests" (1975, p. 64).
} 
Thus, as the case studies in Sect. 3 will confirm, for each individual case the original context of step 1 needs to be reconstructed in quite some detail, in order to determine if the accusation in step 2 and/or the denial in step 3 make sense. This involves assessing whether the hearer's interpretation of the speaker's original utterance is cooperative given the conventional meaning of the words, ${ }^{13}$ their more or less conventionalized implicatures, and the specific context in which they were used (cf. Morency et al. 2008, p. 213).

\section{Analysis of the Data}

In this section we present case studies showing how people defend themselves against an accusation of having said something inappropriate. Section 3.1 discusses cases concerning the denial of literal meaning (scenario 1); Sect. 3.2 deals with data concerning the denial of implicated content (scenario 2).

\subsection{Denying Literal Meaning}

Focusing on the cancellation and denial of implicatures, the literature discussed in Sect. 2 presupposes that speakers are highly committed to literal meaning. In fact, in Grice's framework, cancellability is supposed to be the defining feature of conversational implicatures as opposed to "what is said". In reality, however, speakers may deny commitment not only to an implicature but also to the (supposed) literal content of what they said. In large part, this has to do with the fact that even the interpretation of the so-called literal meaning of an utterance is not fixed or context-independent. Language users often say things that are vague and unspecified, or that could never be true when taken literally. Rather, in order to keep communication interesting, we exaggerate, simplify, generalise, make use of figures of speech et cetera. Moreover, our utterances would be far too lengthy and become obscure if we would always specify in every detail what we actually mean, making communication non-efficient. Taking into account as well the widespread polysemy of lexical items and grammatical constructions, it will be clear that even the "literal" meaning of an utterance is underdetermined to some extent; it may be negotiated and thus leaves some room to manoeuvre. Below it will become clear that some strategies by which one can deny commitment to literal meaning exploit the presence of such an "interpretation space".

In the examples that we collected, four types of defence strategies can be distinguished:

(1) Denying having uttered these words altogether;

(2) Providing another "literal" meaning;

(3) Appealing to a non-literal interpretation (implicature);

(4) Coming up with excuses.

\footnotetext{
13 In some sense, linguistic meaning or "what is said" is simply the most conventionalized part of utterance interpretation, but even this aspect may be debated by interlocutors, as will be illustrated in Sect. 3.1.
} 


\subsubsection{Nasty}

Our first case illustrates the first strategy of a blunt denial of even having uttered the alleged words, followed by a strategy of the second category after the denial had been counterfeited with evidence. These strategies were used by Donald Trump when being accused of calling British Royal Princess Megan Markle "nasty". The accusation followed an interview with Trump in The Sun prior to his State Visit to the United Kingdom in June 2019. When the interviewer told Trump about negative remarks that Markle had made about him in 2016, Trump insisted he had not heard these remarks before: "I didn't know that. What can I say? I didn't know that she was nasty", a quote that had subsequently been made public. ${ }^{14}$ When being accused of having called the Princess "nasty", Trump initially denied that he had said so-_I never called Meghan Markle "nasty",15_ and blamed it on the "fake media". He continued denying it even after The Sun had posted the audio recordings, which confirmed the accusation, but Trump responded by telling the public not to believe what they had just heard. ${ }^{16}$

Just before returning home, however, Trump took back his denial on British television. He admitted that he had used the word nasty and took recourse to an alternative defence, by providing an alternative reading of what he had literally saidan instantiation of our second category-boiling down to calling Markle's remarks nasty instead of labelling her personality. As such, Trump argues that he used the word nasty as a stage-level rather than an individual-level predicate in the sense of Carlson (1977). Since different sources provide different quotes, we mention here two of them ${ }^{17}$ :

(7) What she said was nasty based on what they told me.

(8) I wasn't referring to she's nasty, I said she was nasty about me, and essentially I didn't know she was nasty about me.

A White House official told ABC News that the President had not specifically said that Markle was nasty, that he had also said some very nice things about her and that

\footnotetext{
${ }_{14}$ https://www.thesun.co.uk/news/9196110/donald-trump-meghan-markle-nasty-comment-uk-visit $/$ ?utm_medium $=$ Socialandutm_campaign $=$ sunmaintwitterandutm_source $=$ Twitter\#Echobox $=15593$ 80782.

${ }^{15} \mathrm{https} / / /$ twitter.com/realDonaldTrump/status/1135165268261519361.

${ }^{16}$ In response to this blatant denial, comments started circulating in which a sentence of the dystopian novel 1984, written by George Orwell, was cited: "The party told you to reject the evidence of your eyes and ears. It was their final, most essential command." Indeed, there have been other occasions in which Trump denied that he had said something whereas audio or visual evidence proved otherwise (https:// www.nytimes.com/2019/06/05/us/politics/meghan-markle-nasty-trump.html).

${ }^{17} \mathrm{See} \quad$ https://www.msn.com/en-us/video/downtime/trump-tries-to-explain-his-nasty-remark-about -meghan-markle/vp-AACrMyB and https://abcnews.go.com/Politics/president-donald-trump-attemptsexplain-meghan-markle-nasty/story?id=63502352.
} 
the media had taken the quote out of context. ${ }^{18}$ At least in this case, this "out of context" strategy seems a reasonable defence considering the fact that Trump had only been responding to the information provided by the interviewer. This is also how the interviewer himself had taken Trumps words, as he later explained:

(9) I think this is all a bit of a row about semantics (...). If he finished the sentence, I didn't know she was nasty about me, or to me, then clearly he would have been referring to the fact that she was pretty disparaging about the president during his 2016 election campaign. ${ }^{19}$

The appeal to ellipsis in (9) shows that the argument here is one at the level of pragmatic enrichment of linguistically encoded meaning, or disambiguation, rather than one at the level of implicatures, ${ }^{20}$ thus providing a clear example of the "interpretation space" and negotiability of explicit content mentioned above.

\subsubsection{Failed State}

In our second example case, Dutch Minister of Foreign Affairs Stef Blok had been accused of racism and misrepresenting the political situation in Surinam. At a private meeting in The Hague on xenophobia and immigration problems in July 2018 Blok said not knowing of any country where people with different cultural backgrounds live together peacefully. When one of the attendants objected that Surinam is an example of such a country, Blok laughed and replied:

(10) Is it not true that Surinam's political parties are divided along ethnic lines? [Is there] a well-functioning Rule of Law and a democracy? (...) Surinam is a failed state. And the reason for this is its ethnic organisation. ${ }^{21}$

Blok's performance had been filmed by a participant and ended up on Dutch television. The broadcast caused a lot of commotion and even Blok's political friends asked for an explanation. In an initial response to the news programme, Blok acknowledged that he had used words that might have come through in the public debate in an infelicitous way, but he claimed that he had wanted to provoke discussion and stimulate an open exchange of ideas. This strategy of "overstating" the case may be compared to the Cambridge Analytica appeal to hyperbole mentioned in the introduction to this paper. In both cases, commitment to the literal meaning is denied by admitting that the literal meaning may be exaggerated compared to the actual state of affairs (strategy 3). However, in either case, it may be questioned if

\footnotetext{
18 https://abcnews.go.com/Politics/president-donald-trump-attempts-explain-meghan-markle-nasty/story ?id $=63502352$.

19 https://www.washingtonexaminer.com/news/sun-reporter-controversy-over-trumps-nasty-remar k-about-meghan-markle-a-bit-overblown.

${ }^{20}$ In Relevance Theory such phenomena would be treated as explicatures, to be distinguished from both coded meaning and implicatures (cf. fn. 9).

${ }^{21} \mathrm{https} / / / w w w . a d . n l / p o l i t i e k / b l o k-s u r i n a m e-i s-m i s l u k t e-s t a a t-v a n w e g e-e t n i s c h e-o p d e l i n g ~ a 586 a a a b /$ (our translation).
} 
this was really a speaker-intended implicature that the hearer was supposed to pick up on at the time of the original utterance. Indeed, Blok's defence seemed insufficiently convincing and he had to come up with a much more elaborate defence. ${ }^{22}$ To this end, Blok sent a letter to Parliament in which he apologized and "regretted" his "sharp words". But he also added that he had not referred to the usual international definition of a failed state. Instead, he claimed that these words were supposed to mean that it is a weakness of the Surinam political system that its political conditions are highly determined by ethnic groups ${ }^{23}$ :

(11) When I used the phrase failed state, I did not mean the accepted international definition of a failed state. Although different population groups peacefully live together in the greatly varied Surinam society, ethnic origin remains highly determinant in politics. Many Surinam voters vote for candidates from their own ethnic group (not per se for ethnic parties) expecting that these politicians may stand up for their interests in the best way. I meant to say that unfortunately this is a weakness in the political system. ${ }^{24}$

The latter defence, which we qualify as providing an alternative meaning (category 2), seems hardly plausible as it is rather unusual for a Minister to neglect an accepted standard definition. Having used a term in a particular, unusual sense without having indicated that beforehand, does not constitute a convincing argument. Blok's defence does fit in a list of other well-known examples of people coming up with idiosyncratic definitions, usually not shared by anybody else. A notorious example is former US president Bill Clinton's denial of having had sex with Monica Lewinsky. This denial could only be true if sex was to include only sexual intercourse and to exclude other sexual activities (such as oral sex). Naturally, Clinton's strict definition could not convince many people. Be that as it may, both Dutch parliament and Surinam accepted Blok's explanations, which may have been rather a case of political pragmatism than of actually believing the defence to have been convincing.

Like the appeal to hyperbole, two other cases concern the third category of appealing to a non-literal interpretation, more specifically to the use of two other figures of style. In these defences the alternative interpretation is in fact an implicature of the utterance and therefore it constitutes the exact mirror image of scenario 2 , where commitment to an alleged implicature is denied by taking recourse to the literal interpretation.

\footnotetext{
22 https://zembla.bnnvara.nl/nieuws/minister-stef-blok-suriname-is-een-mislukte-staat-door-etnischeopdeling.

${ }^{23}$ Stipulating definitions is a common practice in legal argumentation (cf. van Bree et al. 2003, p. 262).

${ }^{24}$ https://zembla.bnnvara.nl/data/files/175307253.pdf.
} 


\subsubsection{Irony}

The first of these concerns a column written by by Naema Tahir in the Dutch newspaper Trouw. Tahir is Pakistani by birth and wrote about her struggle with the Dutch language. Because her 6-year old daughter always corrects her when she is using the wrong articles, she called for getting rid of the Dutch neuter article het and stick to $d e$ for all nouns irrespective of their gender. ${ }^{25}$ Her argument was full of exclamation marks, rhetorical questions and simplifications and she referred to the class of immigrants to which she herself belongs with the term allochtoontjes ( $\approx$ 'little immigrants'), i.e. a slightly outdated term denoting people with roots outside the Netherlands in combination with a diminutive, which in this case has a denigrating effect (Bakema et al. 1993):

(12) What a waste of time! What discrimination! What a permanent disadvantage of us little foreigners! This must change. I have therefore a proposal. Skip 'het' from our language. Replace it by ' $d e$ '. (...) 'Het' forms a minority anyway. The vast majority of words go with ' $d e$ ' as an article. So, it is not a very big operation. Think of how much time will be gained! Think of the progression that will be realised with the immigration in one single step! We are all equal. Hence, let's equalize our articles too! So I say: away with 'het'! (Trouw 20 December $2018)^{26}$

The way this text is formulated offers more than enough clues for a non-literal reading. Although there were enough people who got the irony, there were also many who did not get it and who overloaded Tahir with huge piles of verbal abuse. In her next column, Tahir reported about the name-calling and made explicit that her former column should not have been taken literally ${ }^{27}$ :

(13) Did I mean that literally? Of course not! (...) I expected that every reader of the column would see through the irony immediately and would chuckle about it with me. Would you not agree that it is evident that that we cannot abolish

\footnotetext{
${ }^{25}$ Dutch has two definite articles, de (for masculine and feminine nouns) and het (for neuter), a distinction that is notoriously difficult to learn at a later age.

26 https://www.trouw.nl/samenleving/schrap-het-uit-onze-taal-dat-is-goed-voor-de-integratie ac961ed6/ (our translation).

27 The case of Tahir was mentioned in another newspaper article claiming that people do not recognize irony anymore nowadays, that they increasingly need more obvious clues, with the risk that too much explicitness ruins the joke: https://www.nrc.nl/nieuws/2019/01/18/ironisch-schrijven-in-de-krant-oftew el-het-taboe-van-de-dubbele-bodem-a3650892?utm_source=NRC\&utm_medium=banner\&utm_campa ign=Paywall\&utm_content=paywall-mei-2019.
} 
articles? And that a proposal of the kind should not be taken literally but as ironic humour? (Trouw, 3 January 2019) ) $^{28}$

\subsubsection{Metaphor}

The other example of appealing to a non-literal reading (strategy 3) concerns an appeal to metaphor. In 2011, the Dutch politician Raymond de Roon was accused of calling Turkish president Erdogan "an Islamic ape". The accusation came up when he had created his own variant of a Dutch proverb literally saying "The ape comes out of the sleeve", which means that finally things have become clear (like English "The cat is out of the bag"). More specifically, after having called Erdogan's language towards Israel "warlike rhetoric" that should be condemned by the Dutch government, he said:

(14) (...) the Islamic ape has come out of the sleeve once again. This time his seat is in Ankara and his name is Erdogan. It is crystal clear that Erdogan is doing this to strengthen his position in the Islamic world. ${ }^{29}$

Political opponents accused de Roon of having called Erdogan an ape and demanded that the Minister of Foreign Affairs would distance himself from this qualification, which he did by calling it an inappropriate metaphor. ${ }^{30}$ De Roon himself acknowledged having used a figure of style and claimed that he had used the imagery to make clear that Erdogan "had shown his real nature".

De Roon's explanation got support from some respectable newspapers, but also met with doubt. ${ }^{31}$ In our view, one can sincerely doubt the figurative explanation of the phrase "Islamic ape". Whereas it is true that de Roon used a Dutch proverb that by definition cannot be taken literally, ambivalence has been created by inserting an adjective in the fixed phrase, attributing a religion to the "ape", and then giving it a name in the following sentence. In the proverb meaning, the ape is the truth that finally comes out. This interpretation gets a strange twist if the ape (referred to with his in the following sentence) is supposed to refer to a person at the same time. The utterance is at least ambiguous, whereas at worst this is a case of "calculated ambivalence" (Engel and Wodak 2013; Hatakka et al. 2017) or "double speak" (Bull and Vandenbergen 2014), i.e. a case in which one can deny a possible interpretation while at the same time conveying exactly that message for those who are happy

\footnotetext{
${ }^{28}$ https://www.trouw.nl/samenleving/schrap-het-uit-onze-taal-dat-is-goed-voor-de-integratie ac961ed6/ (our translation).

29 http://luxetlibertasnederland.blogspot.com/2011/09/islamitische-aap-uit-mouw-erdogan.html (our translation).

${ }^{30}$ https://www.trouw.nl/nieuws/rosenthal-distantieert-zich-van-pvv-opmerking bdf6c96b/.

31 For support see https://www.hpdetijd.nl/2011-09-23/wilders-heeft-gelijk-rutte-was-verkeerd-ingelichtover-de-islami/; https://www.nrc.n1/nieuws/2011/09/26/doe-lekker-zelf-normaal-12037067-a1043890; for doubt see https://www.dagelijksestandaard.n1/2011/09/lesje-grammatica-voor-pvvers/; https://www.volks krant.nl/nieuws-achtergrond/-had-wilders-niet-een-beetje-gelijk- bb54c9b8/.
} 
to receive it (see also Walton 1996; Lee and Pinker 2010, who speak of "plausible deniability").

\subsubsection{Coming Up with Excuses}

As for the fourth and final strategy, a brief discussion will suffice. This strategy of coming up with excuses amounts to, for instance, saying that the utterance was just a slip of the tongue, or by claiming inebriation, or even a hack of one's email or twitter account. For instance, a claim of drunkenness came from Leiden University students after having been accused of using plain racist language against members of "Kick out Zwarte Piet". ${ }^{32}$ And when abusive language had been sent from Dutch comedian Erik van Muiswinkel's twitter account in the direction of Zwarte Piet supporters, van Muiswinkel claimed that his account had been hacked. ${ }^{33}$ It is not necessary to study all these cases in much detail, because assessing the reasonableness of this category of defences does not really depend on an analysis of step 1 and step 2, i.e. on the way the alleged utterance has been phrased and the way it could reasonably be interpreted. The excuses that we found can be put forward in all kinds of cases: they do not bear on an interpretation of what has been said and, in fact, the accused is not denying having said it anyway. Possessing some knowledge of the speaker might help to assess the plausibility of the excuse, for instance knowing if the arguer uses alcohol at all and how much, what their political views are, etc. But if one does not have this knowledge, the claims falling within this category cannot be checked and thus not be assessed. Arguers making use of this category of defence are therefore often to be "taken for their words". On the one hand, this arguably makes the defence a rather weak one, but from the perspective of effectiveness it may function as an immunization technique (van Eemeren and Grootendorst 1992, p. 119), since questioning the excuse boils down to calling the accused a liar.

We will conclude this section with a rather hilarious example of the fourth defence strategy concerning Trump's rectification of his words-at a summit in Helsinki-making use of the excuse of a slip of the tongue. At a press conference held together with Russian President Putin in Helsinki, Trump said, in response to a question, that he did not see any reason why Russia would have been involved in meddling with the American elections of 2016:

(15) (...) people came to me (...); they said it's Russia. I have president Putin; he just said it's not Russia. I will say this: I don't see any reason why it would be. ${ }^{34}$

Only when even prominent Republicans were critical about this statement for its total contradiction with all findings of American intelligence service, Trump

\footnotetext{
32 http://archief.mareonline.nl/archive/2018/12/06/beveiliging-na-racistische-apps.

33 https://www.nu.nl/achterklap/4270257/schelden-erik-van-muiswinkel-twitter-kwam-hackers.html.

34 https://www.theguardian.com/us-news/2018/jul/19/would-or-wouldnt-how-trumps-claim-he-missp oke-unleashed-a-meme-fest.
} 
declared that he had misspoken, i.e. that it had been his intention to include a negation in the sentence. After berating reporters for not understanding he had meant the exact opposite of what he had said, Trump clarified his position on Russian meddling in the election on his return to Washington:

(16) I thought it would be obvious, but I would like to clarify just in case it wasn't. In a key sentence in my remarks, I said the word 'would' instead of 'wouldn't'. (...) The sentence should have been: 'I don't see any reason why I wouldn't, or why it wouldn't be Russia,' sort of a double negative. So you can put that in, and I think that probably clarifies things pretty good by itself. ${ }^{35}$

The British newspaper The Guardian called Trump's retraction "an extraordinary attempt to walk back remarks". Although, in the first place, Trump's personality makes it hard to believe his excuses, what made the denial in this case even more incredible was his initial response to the criticisms, that had started immediately after the press conference. In another tweet sent from his airplane that would bring him home, he more or less explained his earlier betrayal of the US Intelligence Services:

(17) As I said today and many times before, "I have GREAT confidence in MY intelligence people." However, I also recognize that in order to build a brighter future, we cannot exclusively focus on the past-as the world's two largest nuclear powers, we must get along! \#HELSINKI2018 36

It was therefore not surprising that Trump's claim of having misspoken was met with incredulity and evoked many hilarious responses on the internet. ${ }^{37}$

\subsection{Denying Implicature}

The defence strategies that are used in our examples of denying commitment to an implicature, bear some resemblance to the defence strategies discussed in the previous section. ${ }^{38}$

(1) Denying the alleged implicature;

(2) Appealing to another implicature;

\footnotetext{
35 Ibidem.

36 Ibidem.

37 The Guardian even described it as "unleash[ing] a meme-fest" because Trump's denial was copied it to other situations. Contributions to the 'meme-fest' were, for example: "It all makes sense now. When Trump said that Mexico "would" pay for his stupid wall, he really misspoke and meant that Mexico \#wouldn't pay for the wall”, and “Trump: "I said Mexicans are rapists. I misspoke. I meant to say they're rakists, like they rake leaves and stuff, probably illegally, but whatever. I'll build a wall and make them pay for it. Anyway, that's what I meant to say_rakists, bigly."\#Wouldnt \#Snark".

38 In Sect. 4, we will compare the two scenarios in more detail.
} 
(3) Coming up with excuses.

The first two strategies occur both in "blunt" form (i.e. just a denial or an appeal to another implicature), but also in combination with supporting reasons in order to downplay the plausibility of the alleged implicature [in case of strategy (1)] or to increase the plausibility of an alternative implicature [in case of strategy (2)]. The first two strategies have in common that commitment to the contested implicature is denied. This is an important difference with the third strategy. An appeal to excuses boils down to acknowledging the implicature as speaker intended (at the time) and defending oneself by coming up with an "external" explanation (of the same kind as discussed in Sect. 3.1.5).

\subsubsection{Je ne Regrette Rien}

Our first case study illustrates a blunt denial of an alleged implicature. In 2013, the then Dutch Minister of Foreign Affairs, Frans Timmermans, was faced with criticism concerning a post on his Facebook page. Timmermans had posted a link to a Youtube video in which Édith Piaf performs her famous song Non, je ne regrette rien ('No, I don't regret anything'):

(18) Today 50 years ago she died. But her music has proven to be immortal. http:// youtu.be/rzy2wZSg5ZM

At the time Timmermans posted his message, 9 October 2013, the Netherlands and Russia were engaged in a serious diplomatic conflict. The cause of this conflict was the apprehension of a Russian diplomat, Dmitri Borodin, in The Hague a few days earlier. According to the Dutch police, Borodin had been arrested because of drunkenness and because he was suspected of mistreating his children. Since embassy staff members have diplomatic immunity according to the Vienna Convention, Russia demanded prosecution of the police officers involved as well as official apologies from the Dutch government. Although the police officers were not brought to account, Timmermans did indeed apologize officially in name of the Dutch government on October 8. One day later, Timmermans posted the message in (18). Journalists and people on social media interpreted Timmermans' Facebook post as an implicit banter towards Russia, the implicature being that he did not actually regret Borodin's apprehension. However, when being confronted with this accusation, Timmermans denied the implicature by simply saying: "This really has nothing to do with Russia", and "It is truly complete nonsense to attach a political intention to this".

Timmermans' blunt denial turned out to be not very convincing as people continued saying that his message was politically motivated. Timmermans defended himself subsequently by posting the text in (19) on Facebook, which boils down to once again bluntly denying the implicature and claiming that the literal meaning was in fact the only intended message ("Not more, and not less"). 
(19) La Môme died 50 years ago today, and I just commemorate this with a performance of her most well-known song. Not more, and not less.

In this reading, the fact that Timmermans' Facebook message coincided with the diplomatic conflict, should then just be seen as a(n) (un)lucky chance. Timmermans' explanation does not seem unreasonable: at the time of the Piaf-message, he was very active on social media, posting not only politically related messages but also more "personal" ones about his passions, including music. Claiming that he was just commemorating could therefore not easily be discarded by his critics. However, choosing this particular song (instead of another famous song by Piaf, like La vie en rose) enabled him at the same time to evoke a particular conversational implicature bringing across how Timmermans really thought about the diplomatic fusswithout being accountable for that implied message. Thus, Timmermans' post might be seen as another example of "double speak" or "calculated ambivalence" (cf. the "islamic ape" case in Sect. 3.1). ${ }^{39}$

\subsubsection{Racist Tweet?}

In some cases, denying commitment to an implicature comes with additional argumentation to make clear that the alleged implicated reading is not plausible. An example of this we saw in van der Steur's denial that he used the phrase kwetsbare informatie ('delicate information') to suggest removing information from a letter to parliament (Sect. 2.2). Van der Steur defended himself by claiming that if this were his intention, then he "would have said so explicitly". A similar kind of e contrario argument was used by Trump's son to deny that the utterance in (1) had a directive reading (cf. Sect. 1): every time his father issued an order, he did so explicitly and since (1) is not an explicit order, it does not constitute an order at all. ${ }^{40}$

Another example of supporting the plausibility of commitment denial concerns the way in which BBC journalist Danny Baker defended himself against accusations of racism with regard to the new-born baby in the British Royal family. Baker had posted a monkey wearing a human outfit and holding the hand of a woman, accompanied with the text "Royal baby leaves hospital". In response to the public indignation, he apologized and defended himself among other things with the following tweet:

(20) Sorry my gag pic of the little fella in the posh outfit has whipped some up. Never occurred to me because, well, mind not diseased. Soon as those good enough to point out it's possible connotations got in touch, down it came. And that's it. Now stand by for sweary football tweets.

\footnotetext{
39 In the analysis of political discourse, the notions of "double speak" and "calculated ambivalence" are mainly associated with (extreme-) right populism. The example of Frans Timmermans indicates that use of this rhetorical technique may not be reserved exclusively for this type of politicians. See van Haaften (2019: 317) for another telling example.

${ }^{40}$ In argumentation theory, e contrario arguments are traditionally considered to be unreasonable. However, they are not necessarily fallacious; whether they are depends on the answers to the relevant critical questions (cf. Jansen 2008).
} 
In this tweet Baker acknowledges that his message could be interpreted as racist. However, at the same time he maintains that this interpretation had never occurred to him at the moment of writing since, allegedly, his "mind [is] not diseased". His support therefore consists of an appeal to ethos, i.e. to being a right-minded person who is alien to racist thoughts. It could be true that Baker did not have a racist intent, although one must have been living under a stone if one did not foresee the racist layer of the message. Be that as it may, it is doubtful whether Baker's defence convinced his critics as it is based on the counter-charge that reading a racist message in his tweet presupposes having a diseased mind.

In a later series of tweets Baker explained that he selected this specific picture quite randomly for another aim: "attempting to lampoon privilege and news cycle". This defence boils down to appealing to another implicature (strategy 2). For the $\mathrm{BBC}$, it didn't really matter whether Baker's explanation was reasonable or not: he was fired, since Baker, being a journalist, should have realized that the picture in the given context would evoke a racist interpretation. ${ }^{41}$

\subsubsection{The Second Amendment}

The previous examples illustrated ways in which a denial of an alleged implicature can be supported with reasons attacking the plausibility of the implicated reading. Our next case illustrates how an accused person provides reasons supporting his own interpretation of his utterance, i.e. reasons meant to increase the plausibility of an appeal to another implicature. This example case focuses, again, on Donald Trump. In 2016, Trump had to defend himself against accusations of inciting violence against Hillary Clinton after remarks he made in a campaign rally speech in Wilmington, North Carolina (Time 2016). In this speech, Trump warned his audience that it would be "a horrible day" if Hillary Clinton would become the new president, since, according to Trump, she would supposedly abolish the Second Amendment, protecting the right to keep and bear arms. This is what Trump said:

(21) Hillary wants to abolish-essentially abolish the Second Amendment. By the way, and if she gets to pick, [booing] if she gets to pick her judges, nothing you can do, folks. [pause] Although the Second Amendment people, maybe there is. I don't know. [Our italics]

Completing the italicized sentence as "Although [for] the Second Amendment people, maybe there is [something that can be done]", Trump's political opponents read into these words a call for violence against Hillary Clinton. ${ }^{42}$ However, in interviews with CBS and Fox News Trump fiercely denied commitment to such an implicature

\footnotetext{
41 Haugh (2013) discusses similar cases of speakers being accountable for an implicature they claim they did not intend.

42 For instance, Clinton's campaign manager stated that Trumps words were "dangerous"; "a person seeking to be the president of the United States should not suggest violence in any way". https://www. theguardian.com/us-news/2016/aug/09/trump-gun-owners-clinton-judges-second-amendment.
} 
by appealing to another one: he claimed that he was only mobilizing gun rights supporters to vote against Clinton-which is an implicature of another kind. Trump supported this appeal to another implicature by saying: "There can be no other interpretation [than that I was mobilizing gun rights supporters to vote against Clinton]. Even reporters told me-I mean, give me a break." This appeal to what reporters told Trump can be interpreted as an ad populum argument ("I am right since many people, even reporters, agree with this standpoint") or an appeal to authority as one takes into account the fact that reporters are usually said to criticise Trump, which makes them a trustworthy source when they say something in favour of him. In both interpretations, Trump provides a supporting reason to increase the plausibility of the alternative implicature he appeals to in order to defend himself.

One can doubt if Trump's defence is a reasonable one: in the audience sitting behind Trump, several people looked shocked or laughed out loud after Trump uttered the words in (21) showing that his own supporters immediately picked up on the alleged implicature. And although fellow party member Jeff Sessions, who was United States Attorney General at the time in Trump's Cabinet, denied the implicature ("I don't believe that's true. I don't believe that's at all what he meant") he admitted that "[i]t may have been awkwardly phrased". ${ }^{43}$ Still, this does not automatically mean that Trump is actually committed to the implicature since the alternative reading is also a plausible one. It therefore remains hard to assess what Trump actually wanted to say with his controversial wordings. ${ }^{44}$

The case of the Second Amendment remark cited in (21) is interesting for another reason as well. After Trump had been accused of inciting violence against Hillary Clinton, fellow party member Paul Ryan defended Trump using another strategy. Ryan stated that Trump's remarks sounded "like a bad joke", adding: "You should never joke about that. I hope he clears it up quickly." Ryan thus seemed to agree with Trump's critics that Trump's wordings implicated a call for violence, but he suggested that the implicature should not be taken seriously but rather as a form of inappropriate humour. This defence looks like the irony defence in scenario 1 (discussed in Sect. 3.1), but while the latter consists in denying a literal reading by claiming an implicated reading (i.e. the ironic reading), in the case discussed here it is the implicature itself that is supposed to be funny. ${ }^{45}$ Ryan's comment thus presupposes the implicature as part of the intended meaning of the utterance, but also in such a case a speaker may still deny commitment to it, i.e. by using one of the ways in which literal meaning can be denied such as appealing to a humorous interpretation (as an additional implicature). This interpretation seems to be in line with how

\footnotetext{
43 https://www.theguardian.com/us-news/2016/aug/09/trump-gun-owners-clinton-judges-second-amend ment.

44 Trump makes use of the same ambiguity in the following video: https://www.youtube.com/watch ?v=5nwG7ynpeiU. Here he claims that since Hillary is against weapons her body guards should drop them, and "let's see what happens to her that would be very dangerous".

45 Dynel (2018, p. 95) argues that the Gricean notion of making as if to say, covering standard cases of irony such as discussed in 3.1, should be complemented by the notion making as if to implicate, where the implicature rather than the literal meaning is overtly untruthful. The latter is applicable to Trump's remark about the Second Amendment, at least on Ryan's humorous interpretation of this utterance.
} 
some people in the audience perceived Trumps remarks: the response of some people sitting behind Trump laughing after he made his controversial claim.

\subsubsection{Volkert, Where are You?}

As a third, and final strategy, denials of implicatures may also invoke external circumstances, such as the excuses illustrated in Sect. 3.1.5 ("I was drunk", "It was a slip of the tongue", etc.). Characteristic for this strategy is that arguers accept commitment to the implicature they are being accused of to the extent that they admit that the implicated reading was intended (at the time). An interesting defense from this category was offered by a lecturer of the University of Utrecht, used after elections for the Provincial States in the Netherlands, in which Thierry Baudet, leader of the populist party Forum for Democracy was the surprising winner. The lecturer tweeted "Volkert, where are you?"-referring to Volkert van der Graaf, the man who killed the Dutch politician Pim Fortuyn in 2002. When the lecturer was accused of inciting violence against Baudet, he apologized for his tweet, stating:

(22) In the heat of the election battle I posted yesterday evening a comment that I didn't mean literally. I did not mean what I said, and I distance myself fiercely from it.

Paradoxically, by saying that he did not mean his comment "literally", the lecturer is not distancing himself from the literal question ("Volkert, where are you?"), but, instead, from the alleged implicature of calling for violence against Baudet. But this makes even more clear that he acknowledges the implicature he is being accused of as part of the communicated meaning. As a defense strategy he then chooses to appeal to external circumstances by claiming that he posted his controversial message "in the heat of the moment". 46

\section{Defence Strategies along the Lines of Classical Rhetorical Status Theory}

In this section we will show that the defence strategies that we presented in Sect. 3 can be classified insightfully in terms of classical rhetorical status theory. Status theory is supposed to be developed by Hermagoras of Temnos in the second century B.C. and distinguishes four issues (status) that can be at stake in a legal case (Leeman and Braet 1987, pp. 76-90; Kienpointner 1997, p. 229; Braet 2007, pp. 221-227). Both an accuser and a defender can resort to one or more of these issues while making their case; the issues provide the main arguments for their stance. See Fig. 3 for the issues and the lines of defence they generate for a defendant.

${ }_{46}$ https://nos.nl/artikel/2277151-universitair-docent-op-non-actief-na-opmerking-over-baudet.html. 


\begin{tabular}{|l|l|}
\hline Status & Defence strategy used by the defendant \\
\hline $\begin{array}{l}\text { (1) Coniectura: was the } \\
\text { action performed? }\end{array}$ & Denying having performed the act \\
\hline $\begin{array}{l}\text { (2) Definitio: how should } \\
\text { the act be defined? }\end{array}$ & Redefining the act in such a way that it is not illegal anymore \\
\hline $\begin{array}{l}\text { (3) Qualitas: was the act } \\
\text { justified? }\end{array}$ & $\begin{array}{l}\text { Appeal to mitigating circumstances, for instance: } \\
\text { - the deed has been provoked } \\
\text { - others do it too } \\
\text { - I have been forced to do it } \\
\text { - a case of force majeure } \\
\text { - I didn't realize what I was doing / appeal to an unsound mind } \\
\text { - choice of the lesser of two evils (the alternative was worse) } \\
\text { - the advantages of the act outweigh its illegality } \\
\text { - apology (mistake, didn't have bad intentions) }\end{array}$ \\
\hline $\begin{array}{l}\text { (4) Translatio: has the } \\
\text { (legal) procedure been } \\
\text { executed correctly? }\end{array}$ & \begin{tabular}{l} 
Appeal to a wrong judge \\
\hline
\end{tabular} \\
\hline
\end{tabular}

Fig. 3 Main lines of defence according to status theory

The four status go from the strongest (1) to the weakest (4) one as each subsequent status presupposes the former. The second line of defence admits having committed the act, the third admits that the committed act was illegal and the fourth admits all that and also that there are no circumstances by which the deed can be excused.

If we look at the strategies that were discussed in Sect. 3, some clear parallels can be drawn with the status lines in Fig. 3. It is immediately clear that the first strategy of scenario 1-a denial of having uttered the contested words altogether-is an instance of the first status line. Although we did not discuss this line of defence for scenario 2 , denying the locution can certainly be a potential line of defence here as well: if the accused never uttered the alleged words then he certainly cannot be held accountable for their implicatures ("I did not say X, let alone mean Y"). ${ }^{47}$ It is also clear that coming up with excuses in both scenarios can be regarded as an instantiation of the third classical status of appealing to mitigating circumstances.

What does this leave for the second and fourth status? In our view, any defence line having to do with the intended meaning or interpretation of the utterance instantiates the second status of "redefinition". This, then, includes appealing to another "literal" meaning or to a non-literal reading of specific terms or full propositions in scenario 1 as well as denying an implicature and/or providing an alternative one in

\footnotetext{
${ }^{47}$ In fact, Trump's initial reaction to the accusation regarding the words cited in (1) constitutes a case in point: whereas the accusation concerns the directive implicature of these words, Trump simply denied having uttered these words altogether.
} 


\begin{tabular}{|l|l|l|}
\hline Status & Scenario 1: Denying literal meaning & Scenario 2: Denying implicature \\
\hline Denial & I did not utter $\mathrm{p}$ & I did not utter $\mathrm{p}$ (let alone implicate $\mathrm{q}$ ) \\
\hline (1) Denying having uttered $p$ altogether & $\begin{array}{l}\text { I did not mean } \mathrm{p} \text { ( } \mathrm{p} \text { means something else) } \\
\text { (2) Providing another "literal" meaning } \\
\text { (3) Appealing to a non-literal interpretation }\end{array}$ & $\begin{array}{l}\text { I did not mean } q \text { ( } \mathrm{q} \text { is not an implicature of } \mathrm{p} \text { ) } \\
\text { (2) Appealing to another implicature }\end{array}$ \\
\hline $\begin{array}{l}\text { External } \\
\text { circumstances }\end{array}$ & $\begin{array}{l}\text { I should not have said } \mathrm{p} \text { but there are mitigating } \\
\text { circumstances } \\
\text { (4) Coming up with excuses }\end{array}$ & $\begin{array}{l}\text { I should not have said } \mathrm{p} \text { and implicated } \mathrm{q} \text { but } \\
\text { there are mitigating circumstances }\end{array}$ \\
\hline Wrong judge & $\begin{array}{l}\text { I should not have said } \mathrm{p} \text { but who are you to } \\
\text { blame me? }\end{array}$ & $\begin{array}{l}\text { (3) Coming up with excuses } \\
\text { are you to blame me? }\end{array}$ \\
\hline
\end{tabular}

Fig. 4 Defence strategies of scenarios 1 and 2 along the lines of classical rhetorical status theory

scenario 2. Moreover, by including a fourth status line, the theory suggests a further line of defence that may be used to deny speaker commitment, i.e. something like: "Who are you to judge"? This defence line boils down to discrediting the accuser by means of an ad hominem argument, e.g. by doubting this person's ability to judge, by claiming bias or saying that the accuser himself often speaks in an unacceptable way. In fact, our data do contain a defence of this kind, but we did not discuss it as such yet: Trump's scoffing, in the "nasty" case, of the "fake news" media (see Sect. 3.1) can be seen as an instantiation of this defence line. ${ }^{48}$

Figure 4 above shows how the strategies discussed in Sect. 3 can all be classified in terms of their rhetorical status:

In our view, status theory does not only provide us with a tool to systematize the defence strategies of Sect. 3, but also with a clue for determining speaker commitment. We take it that the assessment of the plausibility of the various strategies indicates the degree of speaker commitment to the literal content and/or the implicature(s) of the original utterance. As the first line of defence (not having uttered the words altogether) is the strongest one and the fourth (attacking the accuser) is the weakest one, this means that a successful appeal to the first status indicates the lowest commitment, whereas an appeal to the fourth status suggests the highest degree of commitment. It should be noted however, that this supposed gradation in strength only holds on the condition that a chosen line of defence is a plausible one and is likely to be accepted. The idea that the status varies in strength should therefore not be confused with what is the best or most effective line of defence in a

\footnotetext{
${ }^{48}$ Danny Baker (Sect. 3.2) is perhaps also exploiting this strategy when saying that one has to have a diseased mind to read his tweet in a racist way.
} 
specific case. The latter is very much dependent on the specific circumstances of the context: if someone is caught in the act, it is definitely not a good strategy to plead not guilty (first status). In what follows we will discuss some contextual factors that affect the plausibility of a specific line of defence.

\subsection{Denial}

As for the first line of defence (denial), arguing convincingly that one did not utter the words altogether will often be difficult. Accusations in the private sphere usually come from someone to whom the contested words were spoken, whereas the sayings of public persons are often recorded by the media or heard by bystanders. It was precisely for this reason that Trump's claim of having spoken no words at all that could be interpreted as a nasty qualification of Megan Markle did not hold. This defence failed as soon as the tapes had been published online, urging Trump to take recourse to another line of defence.

\subsection{Redefinition}

Because of the difficulty to make a successful appeal to status one, an appeal to the second status (definition) may often be a stronger type of defence. Be that as it may, stronger and weaker instantiations can be distinguished within this category. A first and crucial criterion determining the plausibility of this line of defence is conventionalization, i.e. the degree to which the interpretation of the utterance under attack is generally accepted. It can therefore be claimed that-in general-providing an alternative reading is easier if one is being accused of triggering an objectionable implicature (scenario 2) ${ }^{49}$ than if the literal content is at stake (scenario 1). Not for nothing did we assess Minister Blok's idiosyncratic redefinition of a failed state as not very convincing (Sect. 3.1). In contrast, in Sect. 3.2, we saw that Timmermans could get away with his "I don't regret anything" remark, and the same holds for van der Steur when he talked about "delicate information" and Trump's second amendment remark. In all these cases, the discussion concerns particularized implicatures rather than in any way conventionalized aspects of utterance interpretation. It should be added though that scenario- 2 defences become much stronger if one comes up with a plausible alternative reading than if one just states that one did not intend the implicature.

The above does not imply that appeals to the second status in scenario 1 are always weak. For instance, Trump's claim that his (literal) "nasty" remark was taken out of context was fairly reasonable. If the context supports such a defence, it can be pretty strong. Moreover, if literal meaning is denied with an appeal to implicated meaning, like Tahir did in her plea to get rid of the neuter article het in Dutch and

\footnotetext{
49 In Sect. 2.2, we showed that Gricean conventional implicatures and generalized conversational implicatures behave like literal content in this respect, so, in terms of Grice's framework, scenario 2 basically concerns particularized conversational implicatures.
} 
de Roon did by talking about the Islamic ape coming out of the sleeve, arguers also have a fair chance to get away with this, provided that there are linguistic clues rendering the implicated meaning a likely one. In fact, appealing to an implicature ("I did not mean this literally") may offer the best opportunities for an appeal to the second status in scenario 1. Even if this strategy meets with doubt, literal meaning always underdetermines interpretation which makes it difficult to tie the speaker down to one meaning, as we saw in de Roon's remark about the Islamic ape.

We conclude our discussion of the second line of defence with three other criteria that should be taken into account while evaluating defences that appeal to a non-literal interpretation in scenario 1 . The first is the activity type the original utterance is part of. For instance, a column offers more room for being ironic than, for instance, a political context, and, in advertising, hyperbole is expected and accepted. The second criterion is knowledge of the arguer's personality. What is their usual way of speaking, what sense of humour do they have, what are their political views? And, finally, when we are dealing with spoken rather than written language, intonation, gestures and facial expression will be important to assess the interpretation of an utterance. ${ }^{50}$

\subsection{External Circumstances and Wrong Judge}

The third and fourth status are rather weak, because they admit both the locution and its unfavourable meaning or interpretation. The status of circumstances, with strategies like appealing to the "heat of the moment", "having been drunk" or saying that it was "a slip of the tongue" are unverifiable and should be accepted on account of the speaker's authority. However, there is some rhetorical strength in these strategies because saying that one does not believe the reason provided amounts to calling the arguer a liar. The status of appealing to a wrong judge is the weakest one: arguers who appeal to this status completely neglect the contested wording and simply launch a counter attack.

All in all, status theory does not provide a "magic wand" for assessing speaker commitment, but as we have argued above, it is a useful tool to get a grip on the degree of speaker commitment in cases in which arguers have to defend themselves for what they (allegedly) said or implicated.

\section{Conclusion}

In this paper we reported on an empirical study of the ways arguers defend themselves against an accusation of having said something unacceptable. By looking at the plausibility of such defences, we aim to contribute to the study of speaker commitment. To this end, we categorized our data along the lines of classical rhetorical status theory and developed some criteria for the evaluation of each of these status

\footnotetext{
${ }^{50}$ In some cases it is, furthermore, possible to take into acount audience reactions, as we did for the Richard Groenendijk joke in (6) and for Trump's remark about the Second Amendment discussed in Sect. 3.2.
} 
when used as a defence in scenario 1 (denying literal meaning) or scenario 2 (denying implicatures).

In our view, the approach defended in this paper offers a fruitful addition to theoretical discussions about commitment conducted in pragmatics, often relying on standard or fictional examples. Moreover, whereas most of the pragmatics literature focuses on denial of implicature (scenario 2), our study shows that it is important to include denial of literal meaning (scenario 1) in this discussion, since literal meaning appears to be negotiable as well. In fact, our analysis of actual cases reveals that the two scenarios are more similar than would be expected, making use of the same kind of strategies. In any case, by including denial of literal meaning and a systematic categorization of defence strategies in terms of status theory, a fuller picture of commitment denial has emerged.

Open Access This article is licensed under a Creative Commons Attribution 4.0 International License, which permits use, sharing, adaptation, distribution and reproduction in any medium or format, as long as you give appropriate credit to the original author(s) and the source, provide a link to the Creative Commons licence, and indicate if changes were made. The images or other third party material in this article are included in the article's Creative Commons licence, unless indicated otherwise in a credit line to the material. If material is not included in the article's Creative Commons licence and your intended use is not permitted by statutory regulation or exceeds the permitted use, you will need to obtain permission directly from the copyright holder. To view a copy of this licence, visit http://creativecommons.org/licen ses/by/4.0/.

\section{References}

Bakema, P., P. Defour, and D. Geeraerts. 1993. The semantic structure of the diminutive. Forum der Letteren 34(2): 121-137.

Birner, B.J. 2013. Introduction to pragmatics. Oxford: Wiley-Blackwell.

Boogaart, R. 2020. Expressives in argumentation. The case of apprehensive straks ('shortly') in Dutch. In From argument schemes to argumentative relations in the wild: A variety of contributions to argumentation theory, ed. F. van Eemeren and B.G. Garssen, 185-204. Cham: Springer.

Braet, A. 2007. Reasonableness in classical rhetoric. Leiden: Leiden University Press.

Branum, J. K. 2018. "We spoke with a certain amount of hyperbole": Strategic manoeuvring, deception and derailment in the discourse of Cambridge Analytica. Student paper, MA-course, Leiden University.

Bull, P., and A.M. Simon-Vandenbergen. 2014. Equivocation and doublespeak in far rightwing discourse: An analysis of Nick Griffin's performance on BBC's Question Time. Text and Talk 34(1): 1-22.

Capone, A., and A. Bucca. 2018. Why did Trump say "I hope you can let Flynn go" to Comey? Pragmemes and socio-pragmatics (A Strawsonian analysis). Pragmatics and Society 9: 208-231.

Carlson, G. 1977. Reference to kinds in English. PhD dissertation, Amherst: University of Massachusetts.

Carston, R. 2002. Thoughts and utterances: The pragmatics of explicit communication. Oxford: Blackwell Publishing.

de Saussure, L., and S. Oswald. 2009. Argumentation et engagement du locuteur: Pour un point de vue subjectiviste. Nouveaux Cahiers de Linguistique Française 29: 215-243.

Dynel, M. 2018. Irony, deception and humour. Seeking the truth about overt and covert untruthfulness. Boston: Walter de Gruyter.

Engel, J., and R. Wodak. 2013. "Calculated ambivalence" and Holocaust Denial in Austria. In Analysing fascist discourse. European fascism in talk and text, ed. R. Wodak and J.E. Richardson, 73-96. New York: Routledge.

Galasinski, D. 2002. The language of deception: A discourse analytical study. Thousand Oaks: Sage. 
Grice, H.P. 1975. Logic and conversation. In Syntax and semantics, vol. 3, Speech Acts, ed. P. Cole and J.L. Morgan, 41-58. New York: Academic Press.

Hatakka, N., M.K. Niemi, and M. Valimaki. 2017. Confrontational yet submissive: Calculated ambivalence and populist parties' strategies of responding to racism accusations in the media. Discourse and Society 28(3): 262-280.

Haugh, M. 2013. Speaker meaning and accountability in interaction. Journal of Pragmatics 48: 41-56.

Horn, L.R. 2009. WJ-40: Implicature, truth, and meaning. International Review of Pragmatics 1: 3-34.

Jackson, S., Jacobs, S., \& Zhang, X. (to appear). Standpoints and commitments as products of argumentative work: Micro/Macro-Analysis of an infamous press conference. In Paper presented at the 3rd european conference on argumentation, groningen, June 2019, to be published by College Publications.

Jansen, H. 2008. In view of an express regulation: Considering the scope and soundness of a contrario reasoning. Informal Logic 28(1): 44-59.

Kienpointner, M. 1997. On the art of finding arguments: What ancient and modern masters of invention have to tell us about the 'Ars Inveniendi'. Argumentation 11: 225-236.

Lee, J.J., and S. Pinker. 2010. Rationales for indirect speech: The theory of the strategic speaker. Psychological Review 117: 785-807.

Leeman, A.D., and A.C. Braet. 1987. Classical rhetoric. Groningen: Wolters-Noordhoff.

Levinson, S.C. 2000. Presumptive meanings. The theory of generalized conversational implicature. Cambridge: The MIT Press.

Mazzarella, D., R. Reinecke, I. Noveck, and H. Mercier. 2018. Saying, presupposing and implicating: How pragmatics modulates commitment. Journal of Pragmatics 133: 15-27.

Meibauer, J. 2014. A truth that's told with bad intent. Lying and implicit content. Belgian journal of linguistics 28: 97-118.

Moeschler, J. 2013. Is a speaker-based pragmatics possible? Or how can a hearer infer a speaker's commitment? Journal of Pragmatics 48: 84-97.

Morency, P., S. Oswald, and L. de Saussure. 2008. Explicitness, implicitness and commitment attribution: A cognitive pragmatic approach. Belgian Journal of Linguistics 22: 197-219.

Oswald, S. 2010. Pragmatics of uncooperative and manipulative communication. Dissertation, Université de Neuchâtel.

Saul, J. 2012. Lying, misleading, and what is said. An exploration in philosophy of language and in ethics. Oxford: Oxford University Press.

Searle, J.R. 1975. Indirect speech acts. In Syntax and semantics, vol. 3, Speech acts, ed. P. Cole and J.L. Morgan, 59-82. New York: Academic Press.

Snoeck Henkemans, A.F. 2017. Strategic manoeuvring with hyperbole in political debate. In Contextualizing pragma-dialectics, ed. F.H. van Eemeren and P. Wu, 269-280. Amsterdam: John Benjamins.

Time. 2016. Full transcript of Donald Trump's 'Second Amendment Speech'. https://time.com/4445813/ donald-trump-second-amendment-speech/.

van Bree, C., T. van Haaften, and A. van Santen. 2003. Language norms. In Language in use. An introduction in linguistics, ed. T.A.J.M. Janssen, 251-263. The Hague: SdU.

van Eemeren, F.H., and R. Grootendorst. 1992. Argumentation, communication, and fallacies: A pragmadialectical perspective. Hillsdale: Lawrence Erlbaum Associates.

van Haaften, T. 2019. Argumentative strategies and stylistic devices. Informal Logic 39: 301-328.

Walton, D. 1996. Plausible deniability and evasion of burden of proof. Argumentation 10: 47-58.

Weissman, B., and M. Terkourafi. 2018. Are false implicatures lies? An empirical investigation. Mind and Language 34: 221-246.

Publisher's Note Springer Nature remains neutral with regard to jurisdictional claims in published maps and institutional affiliations. 